\title{
DETECTION OF PREGNANCY IN SHEEP USING AN ELISA FOR PREGNANCY-SPECIFIC PROTEIN B
}

\author{
Tímea Milisits-NÉMETH ${ }^{1}$, Orsolya Gabriella BALOGH ${ }^{1}$, István EGERSZEGI ${ }^{2}$, \\ László KERN $^{1}$, R. Garth SASSER ${ }^{3}$ and György GÁBOR ${ }^{1^{*}}$ \\ ${ }^{1}$ National Agricultural Research and Innovation Centre, Research Institute for Animal \\ Breeding, Nutrition and Meat Science, Gesztenyés u. 1, H-2053 Herceghalom, Hungary; \\ ${ }^{2}$ Szent István University, Faculty of Agricultural And Environmental Sciences, Gödöllö, \\ Hungary; ${ }^{3}$ BioTracking, Inc., Moscow, Idaho, USA
}

(Received 16 February 2018; accepted 16 April 2018)

\begin{abstract}
The early detection of pregnancy and the determination of fetal numbers have economic benefits in sheep production because of the seasonal breeding patterns where missing a breeding opportunity means the loss of one productive year. The purpose of this study was to evaluate the efficacy of the B6-HRP ELISA for ovine pregnancy-specific protein B (oPSPB) measurement in the detection of pregnancy and estimation of fetal numbers in different sheep breeds. BioPRYN ${ }^{\circledR}$ ELISA assay kit was used for the detection of pregnancy in the experimental animals. Ninety-three ewes of three breeds (British Milksheep - BM, Lacaune - L and Transylvanian Racka - TR), each from three farms in Hungary, were included in the study. BM and L ewes were artificially inseminated (AI). Thirty-five days after AI, all ewes were examined by transabdominal ultrasound. The TR flock was mated naturally over a six-week period. At the end of the mating period, the ewes were similarly examined by ultrasound. Blood samples were taken from all pregnant ewes twice (35 and 65 days after AI), and serum samples were assayed by the BioPRYN test. It can be concluded that the detection of serum PSPB by ELISA is a much easier, safer, less expensive and highly accurate method for the detection of ovine pregnancy. Although some breed-related differences were detectable at 35 and 65 days post breeding, no differences in oPSPB levels were found in pregnant ewes carrying different numbers of fetuses.
\end{abstract}

Key words: Pregnancy detection, fetal number, pregnancy-specific protein B, ELISA, sheep

The early detection of pregnancy and the determination of fetal numbers have economic benefits in sheep production because of the seasonal breeding patterns where loss of a breeding opportunity means the loss of one productive year. Intensive sheep management and the widespread use of controlled breeding techniques such as artificial insemination (AI) and out-of-season breeding have increased the need for simple, accurate, rapid, cheap and practical methods for early pregnancy detection.

*Corresponding author; E-mail: h12617gab@helka.iif.hu; Phone/Fax: 0036 (23) 319-133 
Approaches to testing have involved the laboratory measurement of the presence of aspartic acid proteinases. The first such proteins, a mixture of several forms of proteins (Sasser et al., 1988), were named pregnancy-specific protein B (PSPB) and were originally detected in the bovine placenta (Butler et al., 1982). The first protein test for pregnancy in ruminants was developed by measuring PSPBs in cows (Sasser et al., 1986). PSPBs are produced in binucleated cells of the fetal trophectoderm (Eckblad et al., 1985). These proteins were detected in several ruminants by radioimmunoassay (Sasser et al., 1988), including a first reference for sheep (Willard et al., 1987) followed by others (Ruder et al., 1988; Ranilla et al., 1994; Willard et al., 1995; Wallace et al., 1997; Karen et al., 2003). Additionally, a radioimmunoassay (RIA) for goat (c) PSPBs in the blood for the detection of pregnancy was first used by Humblot et al. (1990); this was followed by others using blood RIA (Gonzalez et al., 1999) and milk RIA for goats (Gonzalez et al., 2001).

Subsets of PSPBs were found later and were named pregnancy-specific protein 60 (PSP 60; Camous et al., 1988), pregnancy-associated glycoproteins (PAGs; Zoli et al., 1992) and DG-29 (Paré et al., 2008). All are aspartic acid proteinases. An aspartic acid proteinase antigen in binucleated cells of the sheep placenta was found using the monoclonal antibody SBU-3 (Lee et al., 1986). The term PSPB for these proteins will be used herein. The physiological role of PSPB during pregnancy has not been determined but one possible role is the maintenance of the corpus luteum by stimulating prostaglandin E2 production (Del Vecchio et al., 1995).

A qualitative RIA for PSPB for detection of pregnancy in sheep (Ruder et al., 1988) was developed using the bovine (b) PSPB RIA of Sasser et al. (1986). Later, Willard et al. $(1987,1995)$ developed a heterologous quantitative RIA using antibodies specific for ovine (o) PSPB and bovine PSPB as standard and isotope-labelled marker.

Radioimmunoassay is rather hazardous and expensive to use and cannot be applied readily for testing samples. To alleviate these problems, the ELISA technology is more practical. ELISA assays are available for testing bovine (Howard et al., 2007), ovine and caprine PSPB (BioTracking Inc., 2008) as a means of pregnancy detection. The purpose of this study was to evaluate the efficacy of a B6-HRP ELISA for oPSPB measurement in the detection of pregnancy and the estimation of fetal numbers in different sheep breeds.

\section{Materials and methods}

\section{BioPRYN ELISAs for sheep}

The B6-HRP assay (BioPRYN ${ }^{\circledR}$ assay kit) was a typical sandwich ELISA for the detection of pregnancy in sheep and goats, and was supplied by Bio- 
Tracking Inc. (Moscow, ID, USA). Rabbit anti-oPSPB serum was coated to 96well microtitre plates and was used to capture PSPBs of the standards or samples. B6-HRP or MAB45-Biotin was used to bind to the PSPBs that were captured from the standard or sample. If MAB45-Biotin was used, a further incubation with streptavidin-HRP was performed. Development of colour occurred with the addition of 3,3',5,5'-Tetramethylbenzidine, the substrate for HRP. Sulphuric acid $(1 \mathrm{M})$ was used to stop the reaction and an optical density (OD) reading, at $450 \mathrm{~nm}$, was obtained with a plate reader for each well (VersaMax, Molecular Devices, Inc., San Jose, CA, USA).

The cut-off OD reading for each assay plate for evaluating if an ewe was pregnant or not pregnant (open) was determined from the mean OD (triplicate wells) of each of two PSPB standards. Cut-off values were equivalent to the cutoff amount of PSPB found in serum by the RIA for pregnancy testing in sheep (Willard et al., 1995) or goat (Humblot et al., 1990). The sample OD values indicated the amount of PSPBs in a sample, with higher readings having correspondingly higher concentration of PSPBs.

\section{Animals and examinations}

Ninety-three ewes of three breeds (British Milksheep - BM, Lacaune - L and Transylvanian Racka - TR), each from three farms in Hungary, were included in the study. The British Milksheep and Lacaune flocks were housed in a barn by night and were allowed to graze by day. The Transylvanian Racka flock was kept on pasture throughout the experiment. British Milksheep and Lacaune ewes were artificially inseminated (AI). Thirty-five days after AI, all ewes were examined transabdominally by ultrasonography (Pie Medical Falco Vet 100 with 5 7.5 MHz convex transducer, Maastricht, The Netherlands). The Transylvanian Racka flock was naturally mated over a six-week period. At the end of the mating period, the ewes were similarly examined by ultrasound. All pregnant ewes were blood sampled for serum oPSPB analysis twice (first at the positive ultrasound pregnancy diagnosis and the second time 30 days after the first sampling). Blood samples were centrifuged and sera were separated and transported on ice to the laboratory. From the sera, optical density (OD) values for the presence of oPSPB as an indication of pregnancy were determined using the B6-HRP ELISA.

\section{Statistical analysis}

Statistical analyses were done by IBM SPSS Statistics 19 software, using Pearson correlation to study the relationship between OD at day 35 and OD at day 65. Paired sample $t$-test was performed to look for differences between OD at day 35 and OD at day 65. One-way analysis of variance was used to evaluate differences between breeds. 


\section{Results}

Pregnancy was detected by ultrasonography in $22 \mathrm{BM}, 30 \mathrm{TR}$ and $41 \mathrm{~L}$ ewes, respectively. The number of ewes for lambing data recording was reduced because of one abortion in TR and another one in L, and the absence of lambing data for nine TR ewes. Final lambing data were obtained from 22 BM, 20 TR and $40 \mathrm{~L}$ ewes, in the respective breeds. ELISA results were in $100 \%$ agreement with the ultrasound examination findings in $22 \mathrm{BM}, 30 \mathrm{TR}$ and $41 \mathrm{~L}$ pregnant ewes. The pregnancy and lambing data of ewes are presented in Table 1.

Table 1

Comparison of B6-HRP ELISA and ultrasound with the number of ewes lambing

\begin{tabular}{|c|c|c|c|c|c|}
\hline & \multirow{3}{*}{$\mathrm{n}$} & \multicolumn{2}{|c|}{$\begin{array}{c}\text { 1st evaluation, } \\
\text { Day } 35^{*}\end{array}$} & \multirow{2}{*}{$\begin{array}{c}\text { 2nd evaluation, } \\
\text { Day } 65^{*}\end{array}$} & \multirow{3}{*}{$\begin{array}{l}\text { Number } \\
\text { of ewes } \\
\text { lambing }\end{array}$} \\
\hline & & \multirow{2}{*}{$\begin{array}{c}\text { Pregnant by } \\
\text { ultrasound }\end{array}$} & $\begin{array}{l}\text { B6HRP } \\
\text { ELISA }\end{array}$ & & \\
\hline & & & Pregnant & Pregnant & \\
\hline British Milksheep & 22 & 22 & 22 & 22 & 22 \\
\hline Transylvanian Racka & 30 & 30 & 30 & 30 & 20 \\
\hline Lacaune & 41 & 41 & 41 & 41 & 40 \\
\hline Total & 93 & 93 & 93 & 93 & 82 \\
\hline
\end{tabular}

*Ultrasound and a blood ELISA were done at the first evaluation 35 days after AI or at the end of the breeding season (Transylvanian Racka), then a blood ELISA was done 30 days later for all groups

The OD values of all breeds on the 1 st and 2 nd blood sampling dates are shown in Table 2. Using data of all breeds, the 2nd samples (65 days) had higher OD values $(\mathrm{P}=0.013)$ compared to the first samples (35 days). By individual breeds between sampling dates, the OD for the L breed was significantly different with the 65-day value being higher; there was no difference in OD and days sampled for the two other breeds. OD on day 65 was significantly higher only in L ewes, although the two measurements in the other breeds also differed.

Overall, a higher OD was measured in BM ewes than in L ewes, while TR ewes had intermediate OD values.

Table 3 shows the lambing data for the three sheep breeds. All TR ewes had only one lamb per ewe and this differed from MB and L ewes which were similar to each other in the number of lambs born.

In Table 4 , the OD values of the 1 st and 2 nd bleedings are presented with respect to the number of fetuses of British Milksheep and Lacaune ewes. There were no significant differences between OD values, number of fetuses or days of blood sampling. 
Table 2

OD values at days 35 and 65 after breeding among breeds of sheep

\begin{tabular}{|c|c|c|c|c|c|c|}
\hline & \multirow{2}{*}{$\mathrm{n}$} & OD, Day 35 & OD, Day 65 & \multirow{2}{*}{$P$ value } & \multirow{2}{*}{$\begin{array}{l}\text { Correla- } \\
\text { tion }\end{array}$} & \multirow{2}{*}{$\begin{array}{l}\mathrm{P} \text { value } \\
\text { for } \\
\text { correlation }\end{array}$} \\
\hline & & Mean \pm SD & Mean \pm SD & & & \\
\hline British Milksheep & 22 & $0.724 \pm 0.07^{\mathrm{a}}$ & $0.72 \pm 0.09^{\mathrm{a}}$ & 0.857 & 0.501 & 0.018 \\
\hline Transylvanian Racka & 30 & $0.662 \pm 0.10^{\mathrm{ab}}$ & $0.686 \pm 0.11^{\mathrm{ab}}$ & 0.052 & 0.777 & 0.000 \\
\hline Lacaune & 41 & $0.612 \pm 0.13^{\mathrm{bA}}$ & $0.646 \pm 0.13^{\mathrm{bB}}$ & 0.029 & 0.719 & 0.000 \\
\hline All breeds & 93 & $0.654 \pm 0.12^{\mathrm{A}}$ & $0.677 \pm 0.12^{\mathrm{B}}$ & 0.013 & 0.729 & 0.000 \\
\hline
\end{tabular}

a, b: Different letters in columns mean significant differences $(\mathrm{P} \leq 0.05)$ among breeds; A, B: Different letters in rows mean significant differences $(\mathrm{P} \leq 0.05)$ between $\mathrm{OD}$ day 35 and OD day 65

Table 3

Number of lambs born by breed and ewe

\begin{tabular}{lcccc}
\hline & $\begin{array}{c}\text { No. } \\
\text { of ewes }\end{array}$ & No. of lambs & $\begin{array}{c}\text { No. } \\
\text { of lambs } \\
\text { Mean } \pm \text { SD }\end{array}$ & Max. \\
\hline British Milksheep & 22 & 47 & $2.14 \pm 0.889^{\mathrm{a}}$ & 4 \\
Transylvanian Racka & 20 & 20 & $1.00 \pm 0.00^{\mathrm{b}}$ & 1 \\
Lacaune & 40 & 75 & $1.88 \pm 0.563^{\mathrm{a}}$ & 3 \\
Total & 82 & 142 & $1.73 \pm 0.766$ & 4 \\
\hline
\end{tabular}

a, b: Different letters within a column mean significant differences $(P \leq 0.05)$ among breeds; $\mathrm{SD}=$ standard deviation

\section{Table 4}

OD values at days 35 and 65 after breeding by breed and number of lambs born in British Milksheep and Lacaune breeds

\begin{tabular}{lccc}
\hline \multirow{2}{*}{ Number of lambs } & $\begin{array}{c}\text { Number } \\
\text { of ewes }\end{array}$ & OD, day 35 & OD, day 65 \\
\cline { 3 - 4 } & & Mean \pm SD & Mean \pm SD \\
\hline British Milksheep & 5 & & \\
1 & 11 & $0.74 \pm 0.061$ & $0.76 \pm 0.061$ \\
2 & 4 & $0.74 \pm 0.055$ & $0.72 \pm 0.111$ \\
3 & 2 & $0.72 \pm 0.058$ & $0.72 \pm 0.057$ \\
4 & & & $0.66 \pm 0.023$ \\
\hline Lacaune & 9 & $0.64 \pm 0.147$ & \\
1 & 27 & $0.60 \pm 0.138$ & $0.68 \pm 0.145$ \\
2 & 4 & $0.66 \pm 0.122$ & $0.62 \pm 0.121$ \\
3 & & & $0.74 \pm 0.106$ \\
\hline
\end{tabular}




\section{Discussion}

Testing for oPSPB by radioimmunoassay has been reported in the scientific literature (Willard et al., 1995). This paper reports the use of an ELISA for testing oPSPB during certain physiological conditions. The B6-HRP ELISA has been used commercially for the detection of pregnancy through measurement of the presence of oPSPB in serum.

All animals of this study were selected after pregnancy check by ultrasound. All (ultrasound-detected) pregnant ewes had positive ELISA blood samples and were successfully lambing. This indicates the high accuracy of detecting pregnancy at the times of sampling.

The OD values for serum oPSPB increased from 35 days to 65 days when the $\mathrm{L}$ ewes or all ewes were included in the analysis. This is in agreement with the findings of earlier studies (Willard et al., 1995) where the change in oPSPB concentration from early to mid-pregnancy was presented and shown. Although the BioPRYN ELISA test used in this study was a semi-quantitative test and did not provide exact serum oPSPB concentrations, higher OD values refer to higher serum concentrations. This is why OD values are acceptable for the evaluation of correspondence among the different time points and breeds. The lack of difference in OD between BM and TR cannot be readily explained; however, the first sample was taken at 35 days which was only two days earlier than the time when concentrations were similar (37 to 120 days) in gestation by RIA (Willard et al., 1995).

Not surprisingly, all TR ewes lambed only one offspring and both BM (up to 4) and L (up to 3) had increased numbers of multiple delivery. However, no real differences were found in OD values among the ewes that lambed different numbers of offspring (Table 4).

The OD value for oPSPB did not differ at either sampling time regardless of the number of fetuses. This is in contrast to findings of Willard et al. (1995) in sheep and Vasques et al. (1995) in cattle, stating higher serum PSPB concentrations parallel with the presence of more fetuses. Wallace et al. (1997) found that a greater placental mass in sheep was associated with increased circulating PSPB concentration, because of the higher protein production of the binucleated cells of the fetal placenta of cattle (Reimers et al., 1985) and sheep (Lee et al., 1986).

In summary, the detection of serum PSPB by ELISA technology is much easier, safer and less expensive than by radioimmunoassay when testing for pregnancy. The data presented here show that the test is highly accurate and may be used instead of RIA for the detection of ovine pregnancy. In addition, some breedrelated differences were detectable at 35 and 65 days post breeding, but no differences were found between pregnant ewes carrying different numbers of fetuses.

For investigating further the correlations between the number of fetuses and serum oPSPB concentration, the authors plan to conduct examinations by a recently developed MAB45-Biotin ELISA test in the future. 


\section{References}

Butler, J. E., Hamilton, W. C., Sasser, R. G., Ruder, C. A., Hass, G. M. and Williams, R. R. (1982): Detection and partial characterization of two bovine pregnancy-specific proteins. Biol. Reprod. 26, 925-933.

Camous, S., Charpigny, G., Guillomot, M., Martal, J. and Sasser, R. G. (1988): Purification of one pregnancy-specific protein by high-performance liquid chromatography (HPLC). Proc. Bard Workshop, Maternal Recognition of Pregnancy and Maintenance of the Corpus Luteum. Abstract 2, Jerusalem, 20-24 March 1988.

Del Vecchio, R. P. D., Sutherland, W. D. and Sasser, R. G. (1995): Effect of pregnancy-specific protein $\mathrm{B}$ on luteal cell progesterone, prostaglandin, and oxytocin production during two stages of the bovine estrus cycle. J. Anim. Sci. 73, 2662-2668.

Eckblad, W. P., Sasser, R. G., Ruder, C. A., Panlasigui, P. and Kuczynski, T. (1985): Localization of pregnancy-specific protein B (PSPB) in bovine placental cells using glucose oxidaseanti-glucose oxidase immunohistochemical stain. J. Anim. Sci. 61 (Suppl.), 149-150.

Gonzalez, F., Sulon, J., Calero, P., Batista, M., Gracia, A. and Beckers, J. F. (2001): Pregnancyassociated glycoproteins (PAG) detection in milk samples for pregnancy diagnosis in dairy goats. Theriogenology 56, 671-676.

Gonzalez, F., Sulon, J., Garbayo, J. M., Batista, M., Cabrera, F., Calero, P., Gracia, A. and Beckers, J. F. (1999): Early pregnancy diagnosis in goats by determination of pregnancyassociated glycoprotein concentrations in plasma samples. Theriogenology 52, 717-725.

Howard, J., Gabor, G., Gray, T., Passavant, C., Ahmadzadeh, A., Sasser, N., Pals, D. and Sasser, R. G. (2007): BioPRYN - a blood-based pregnancy test for managing breeding and pregnancy in cattle. Proc. West. Sect. Am. Soc. Anim. Sci. 58, 295-298.

Humblot, P., De Montigny, G., Jeanguyot, N., Tetedoie, F., Payen, B., Thibier, M. and Sasser, R. G. (1990): Pregnancy-specific protein B and progesterone concentrations in French Alpine Goats throughout gestation. J. Reprod. Fertil. 89, 205-212.

Karen, A., Beckers, J. F., Sulon, J., Sousa, N. M., Szabados, K., Reiczigel, J. and Szenci, O. (2003): Early pregnancy diagnosis in sheep by progesterone and pregnancy-associated glycoprotein tests. Theriogenology 59, 1941-1948.

Lee, C. S., Wooding, F. B. P. and Brandon, M. R. (1986): Immunogold co-localisation of ovine placental lactogen and the antibody recognized by the SBU-3 monoclonal antibody in sheep placental granules. J. Reprod. Fertil. 78, 653-662.

Paré, J., Audet-Grenier, M-H., Rouillier, P. and Sirard, M-A. (2008): Evaluation of the DG29 test for early detection of pregnancy in cattle. Can. Vet. J. 49, 1119-1121.

Ranilla, M. J., Sulon, J., Carro, M. D., Mantecon, A. R. and Beckers, J. F. (1994): Plasmatic profiles of pregnancy-associated glycoprotein and progesterone levels during gestation in Churra and Merino sheep. Theriogenology 42, 537-545.

Reimers, T. J., Sasser, R. G. and Ruder, C. A. (1985): Production of pregnancy-specific protein by bovine binucleate trophoblastic cells. Biol. Reprod. 32 (Suppl. 1), Abstract 55.

Ruder, C. A., Stellflug, J. N., Dahmen, J. J. and Sasser, R. G. (1988): Detection of pregnancy in sheep by radioimmunoassay of sera for pregnancy-specific protein B. Theriogenology $\mathbf{2 9}$, 905-912.

Sasser, R. G., Ruder, C. A., Ivani, K. A., Butler, J. E. and Hamilton, W. C. (1986): Detection of pregnancy by radioimmunoassay of a novel pregnancy-specific protein in serum of cows and a profile of serum concentrations during gestation. Biol. Reprod. 35, 396.

Sasser, R. G., Williams, R. J., Bull, R. C., Ruder, C. A. and Falk, D. G. (1988): Postpartum reproductive performance in crude protein-restricted beef cows: return to estrus and conception. J. Anim. Sci. 66, 3033-3039. 
Vasques, M. I., Horta, A. E. M., Marques, C. C., Sasser, R. G. and Humblot, P. (1995): Levels of bPSPB throughout single and twin pregnancies after AI or transfer of IVM/IVF cattle embryos. Anim. Reprod. Sci. 38, 279-289.

Wallace, J. M., Aitken, R. P., Cheyne, M. A. and Humblot, P. (1997): Pregnancy-specific protein B and progesterone concentrations in relation to nutritional regimen, placental mass and pregnancy outcome in growing adolescent ewes carrying singleton fetuses. J. Reprod. Fertil. 109, 53-58.

Willard, J. M., Ruder, C. A., Sasser, R. G. and Stellflug, J. (1987): Ovine pregnancy-specific protein B concentration in the sera of early pregnant and peripartum ewes. J. Anim. Sci. 65 (Suppl.), 514.

Willard, J. M., White, D. R., Wesson, C. A., Stellflug, J. and Sasser, R. G. (1995): Detection of fetal twins in sheep using a radioimmunoassay for pregnancy-specific protein B. J. Anim. Sci. 73, 960-966.

Zoli, A. P., Guilbault, L. A., Delahaut, P., Ortiz, W. B. and Beckers, J. (1992): Radioimmunoassay of a bovine pregnancy-associated glycoprotein in serum: its application for pregnancy diagnosis. Biol. Reprod. 46, 83-92. 